\title{
Cardiac troponins and physical exercise. It's time to make a point
}

\author{
Giuseppe Lippi ${ }^{*}$, Gianfranco Cervellin², Giuseppe Banfi ${ }^{3}$, Mario Plebani ${ }^{4}$ \\ ${ }^{1}$ U.O. Diagnostica Ematochimica, Dipartimento di Patologia e Medicina di Laboratorio, Azienda Ospedaliero-Universitaria di Parma, \\ Italy \\ 2U.O. Pronto Soccorso e Medicina d'Urgenza, Dipartimento di Emergenza-Urgenza, Azienda Ospedaliero-Universitaria di Parma, Italy \\ ${ }^{3}$ Istituto Galeazzi e Università di Milano, Italy \\ ${ }^{4}$ Dipartimento di Medicina di Laboraotorio, Azienda Ospedaliero-Universitaria di Padova and Leonardo Foundation, Abano Terme \\ (PD), Italy
}

*Corresponding author: glippi@ao.pr.it, giuseppe.lippi@univr.it

\begin{abstract}
The timely diagnosis of acute coronary syndrome (ACS), in particular myocardial infarction (MI), is still one of the most challenging issues in medicine. The introduction into routine laboratory practice of assays for measuring the cardiospecific troponins has dramatically revolutionized the diagnostic approach and the recent development of methods with improved analytical sensibility (i.e., highly sensitivity [HS] assays), has further contributed to improve the negative predictive value of troponin testing but, contextually, has substantially lowered the clinical specificity of these markers. In particular, clinical studies have demonstrated the existence of an exercise-related increase of HS-troponins, with measurable values detectable in up to $94 \%$ of athletes undergoing endurance sports. This measurable amount of troponin in blood would mirror an increased membrane permeability and early troponin release rather than reflecting a clinically threatening myocardial injury. As such, the measurable amount of cardiac troponins as assessed with the novel HS assays requires major clinical focus (i.e., serial measurement of cardiac biomarkers, detailed clinical historytaking, integration with ECG and imaging findings) to prevent misdiagnosis of ACS and/or Ml in otherwise healthy persons.
\end{abstract}

Key words: sports; biomarkers; acute myocardial infarction; cardiac injury; troponin

The timely diagnosis of acute coronary syndrome (ACS), in particular myocardial infarction (MI), is still one of the most challenging issues in medicine. Despite the relentless introduction of novel biomarkers of myocardial injury over the past decades, the "Holy Grail" seems to be missing as yet. Although the development and introduction into routine laboratory practice of assays for measuring the cardiospecific troponins (namely Troponin I and T) has dramatically revolutionized the diagnostic approach to the patients with chest pain and suspected ACS, the main drawback of cardiac troponins testing has been represented for years by the relative lack in clinical sensitivity, in that up to $50 \%$ of the patients with an ACS had non-diagnostic values on admission $(1,2)$. The recent introduction of methods with improved analytical sen- sibility (i.e., low limit of detection, LOD), traditionally referred to as "highly sensitivity troponins" (HS-Tns) assays, has substantially contributed to improve the negative predictive value of troponin testing but, contextually, has substantially lowered the clinical specificity of these markers (3). Despite the accurate selection of the normal reference population for calculation of reliable cut-off values (i.e., the 99th percentile limit of the reference value distribution [99th URL] obtained with assays with $C V<10 \%$ at those levels), there are still several analytical, physiological and pathological conditions where troponin value is measurable in the absence of a clear ischemic myocardial injury (Table 1) $(4,5)$. Physical exercise, especially when strenuous, must be indeed listed among these causes. 
TABLE 1. Main sources of elevations of cardiac troponins in blood.

\begin{tabular}{l}
\hline Analytical \\
\hline Heterophilic antibodies \\
Rheumatoid factor \\
Microparticles \\
Fibrin clots in the sample \\
Hemolyzed, lipaemic of icteric samples \\
Analytical failure \\
\hline Clinical (cardiac) \\
\hline Myocarditis and pericarditis \\
Pathologies of cardiac valves \\
Hypertrophic cardiomyopathy \\
Severe arrhythmias \\
Severe heart failure \\
Cardiac trauma \\
Chemotherapy toxicity \\
Cardiac amiloidosis and sarcoidosis \\
Rejection of heart transplantation \\
\hline Clinical (extra-cardiac) \\
Pulmonary embolism \\
Acute pulmonary oedema \\
Severe hypertension or hypotension \\
Chronic renal failure \\
Hypothyroidism \\
Stroke \\
Sepsis \\
Snake venom \\
Sickle Cell Disease \\
Physical exercise \\
Ketoacidosis \\
Carbon monoxide poisoning \\
\hline
\end{tabular}

A variety of clinical studies have now clearly demonstrated the existence of an exercise-related increase of HS-Tns (6), with measurable values (i.e., either above the LOD or the 99th URL) being detected in up to $94 \%$ of athletes undergoing endurance exercise (Table 2) (7-30). A recent meta-analysis pooling sixteen studies of 939 participants also showed that there were only 6 pre-marathon cTn elevations ( $0.6 \%)$ but as much as 579 post-race elevations (62\%) (31). Odds ratio for converting from a normal pre-race to an elevated post-race cTn was $51.8(95 \% \mathrm{Cl}=16-168 ; \mathrm{P}<0.001)$. Interestingly, age and gender were not associated with post-race increases, but publication date and assay sensitivity were indeed associated with cTn elevation. Cardiac Tnl was also less commonly ele- vated versus cardiac TnT, which can be explained with the greater sensibility (i.e., low LOD) of the latter assay. As such, the pooled data of the current scientific literature are consistent with the hypothesis that cTn levels might frequently increase after strenuous endurance exercise.

This very frequent occurrence of post-exercise increases of HS-Tns has substantial clinical implications, because diagnostic values in plasma or serum might last for 24 to 36 hours after an acute bulk of physical exercise, and this, in turn if ignored, might dramatically decrease the diagnostic performance of troponin testing, especially in those patients admitted to the emergency department for suspected ACS (32).

Several hypotheses were put forward to explain the biology of troponin increase after physical exercise. Since the current knowledge of myocardial biology has led to definitely rule out that measurable amount of troponins in blood after physical exercise would reflect a clinically threatening myocardial injury, it is now assumed that they would instead mirror an increased membrane permeability and early troponin release (i.e., "leaka$\mathrm{ge}^{\prime \prime}$ ) from the unbound, cytosolic pool, which represents nearly $3-8 \%$ of the total cardiac troponin content $(33,34)$. This hypothesis is supported by the fact that the anatomic variations observed in marathon runners only included dilation of the right atrium and right ventricle, reduction of right ventricular ejection fraction, but no morphological changes were observed in the left atrium or ventricle, nor evidence of ischemic injury to any chamber by late gadolinium enhancement could be detected (35). Similar morphological features were observed by Wilson et al., who concluded that biomarkers of cardiac sufferance after prolonged exercise are not associated with either systolic (i.e., stroke volume or ejection fraction) or diastolic (i.e., early diastolic filling $[E]$, late diastolic filling $[A]$ $E / A$, isovolumic relaxation time, $E$ deceleration time) functional measures (36).

Besides a very low amount of troponin, which is now measurable using most of the novel HS assays and is mainly attributable to cardiac remodelling (i.e., turnover of cardiomyocytes), the stretch-indu- 
TABLE 2. Clinical studies investigating the post-exercise increase of cardiac troponins in endurance sports.

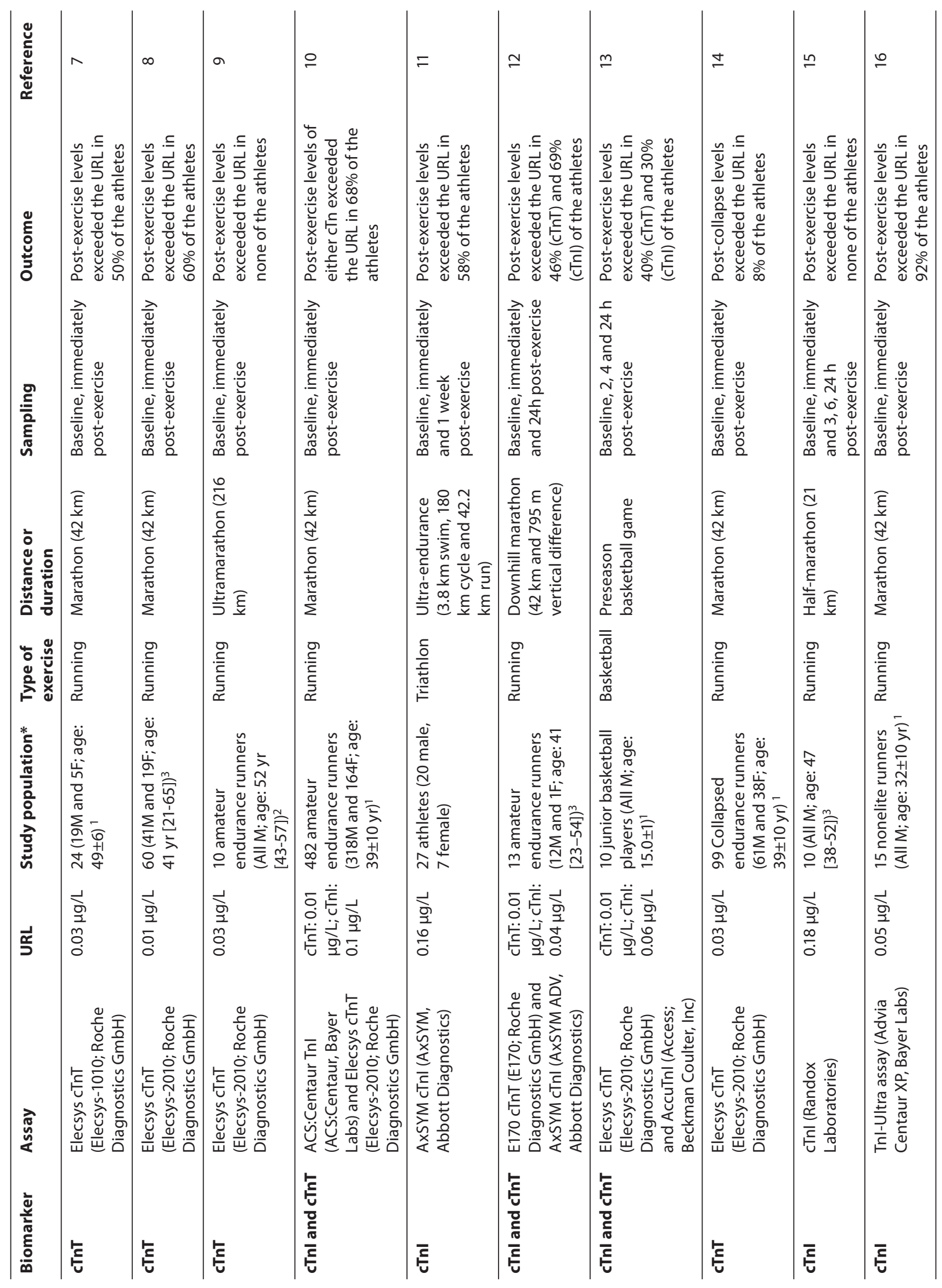




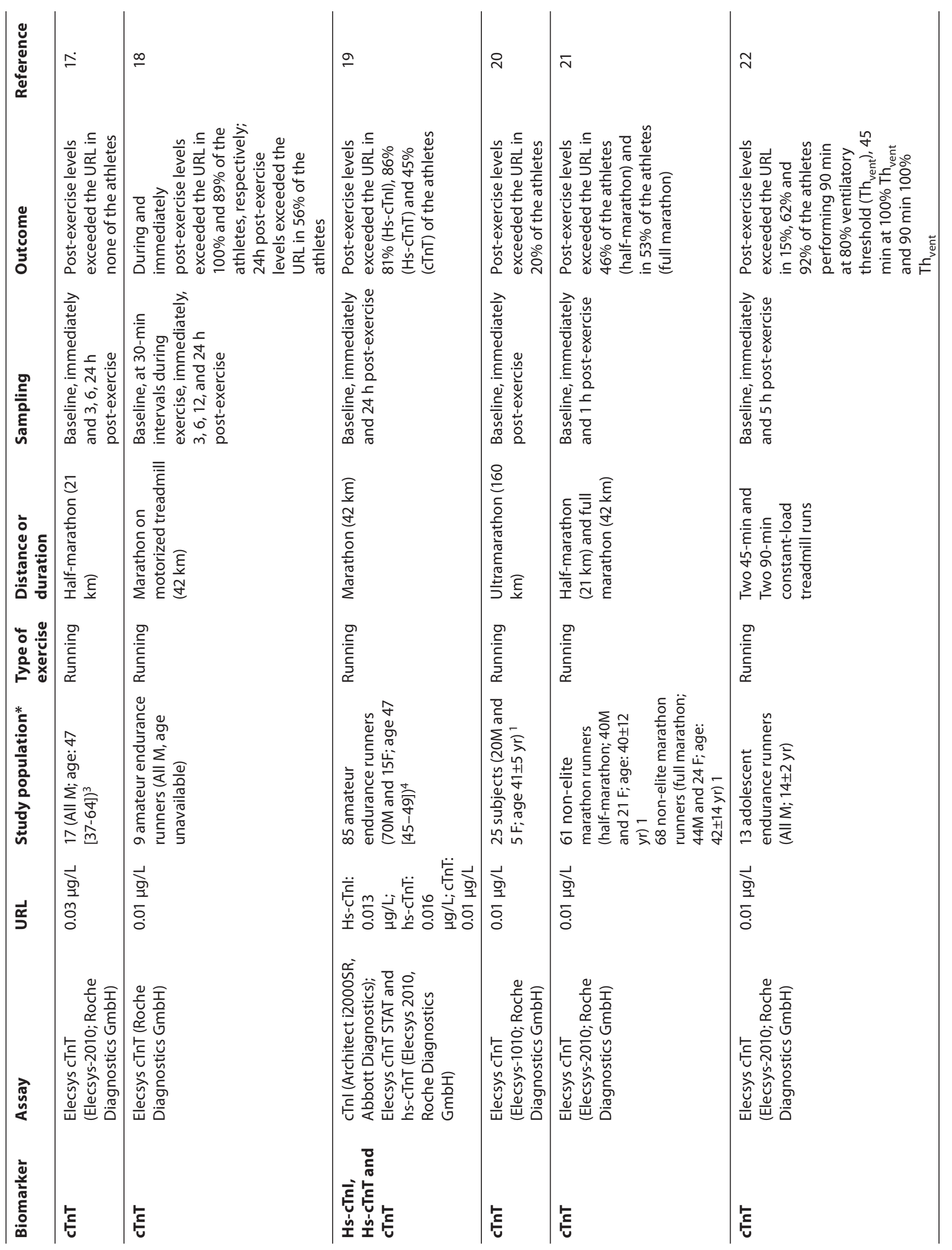




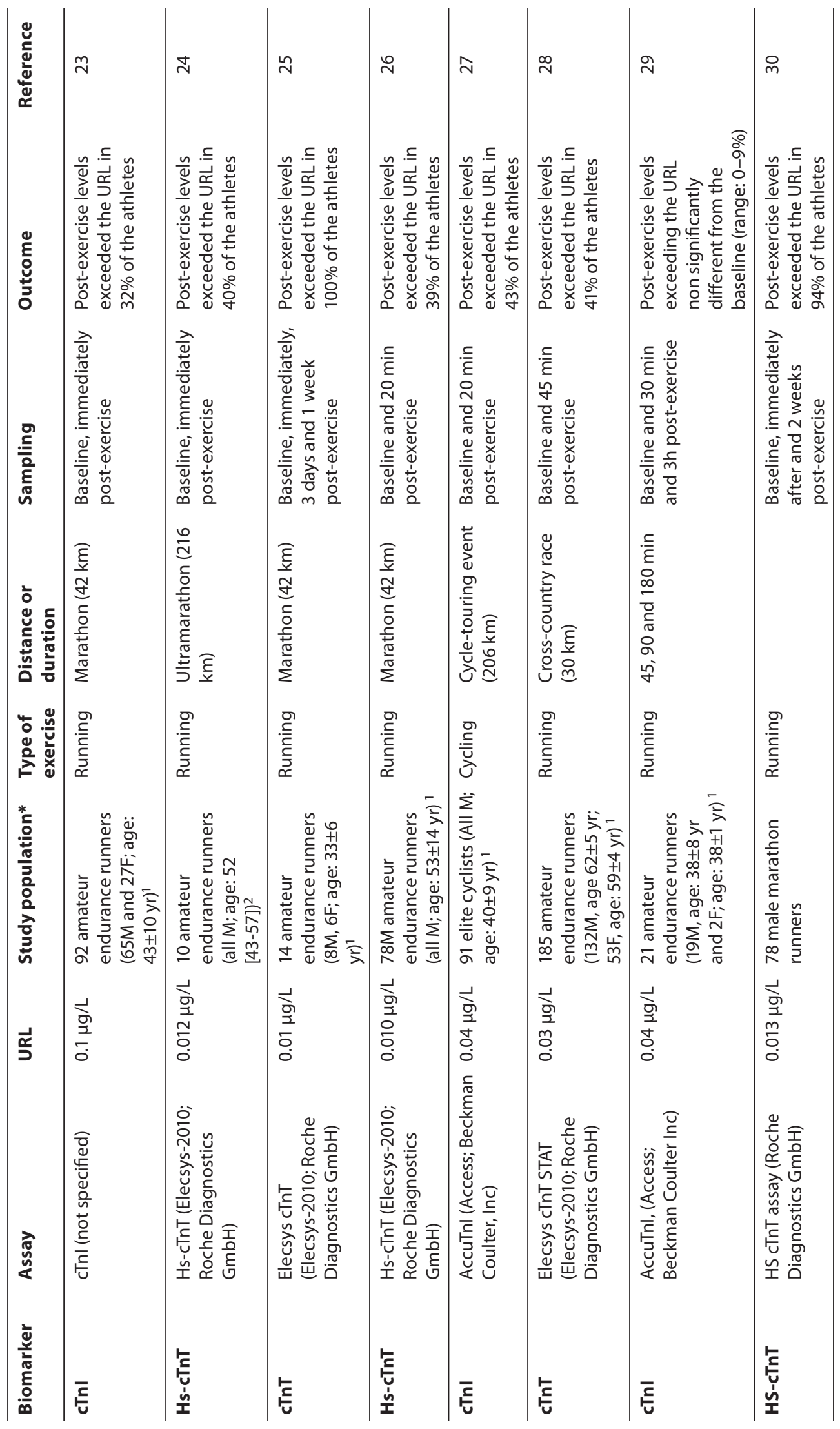


ced release of troponin and its degradation products even in absence of a clear myocardial necrosis has been widely described in several extra-cardiac clinical conditions, such as those listed in table 1. The precise mechanisms of the cellular leakage probably involves a sequence of events, where cardiac ischemia interferes with the normal function of the plasma membrane so that plasma membrane bubbles (also defined "blebs") develop and gradually grow as a function of both severity and duration of ischemia. Transient or mild cardiac ischemic episodes, such as those occurring during physical exercise, might not be sufficient to produce an irreversible membrane injury, so that the blebs are either reabsorbed or shed into the circulation with their protein content, thus justifying the low (usually $<1.0 \mu \mathrm{g} / \mathrm{L}$ ) and short-lasting (typically $<$ 24-36 h) amount of troponin detectable with the new HS assays. Conversely, when re-oxygenation dose not occur timely and cardiac ischemia is thereby prolonged, the blebs at the surface of the plasma membrane tend to collapse rather than be shed into the circulation and the irreversible myocardial injury (i.e., cell necrosis) occurs $(34,37)$. In this instance, the appearance of troponin in plasma is that typical of ACS or MI. As such, the exerci- se-induced myocardium sufferance can be completely repaired and it might even lead to supercompensation.

A further support for this elegant model has recently been provided with the data of O'Hanlon et al, who demonstrated a non significant relationship between cardiac troponins and measures of cardiac damage. In particular, the increase of troponins and other cardiac biomarkers were unrelated with any detectable myocardial damage (inflammation, oedema, hyperemia, or fibrosis) using current gold standard imaging modalities (i.e., cardiovascular magnetic resonance) (38). It is to mention however that the conclusions from Delayed Gadolinium Enhancement (DGE) studies, in which a lack of enhancement has been argued as evidence that myocardial necrosis does not occur, might be questionable inasmuch as the levels of cardiac troponins detectable in athletes is usually less than that defined as the sensitivity limits for necrosis detectable on DGE following percutaneous coronary intervention or myocarditis.

Cardiac abnormalities may be a major source of morbidity in a small number of endurance and recreational athletes. Neilan et al investigated noneli-

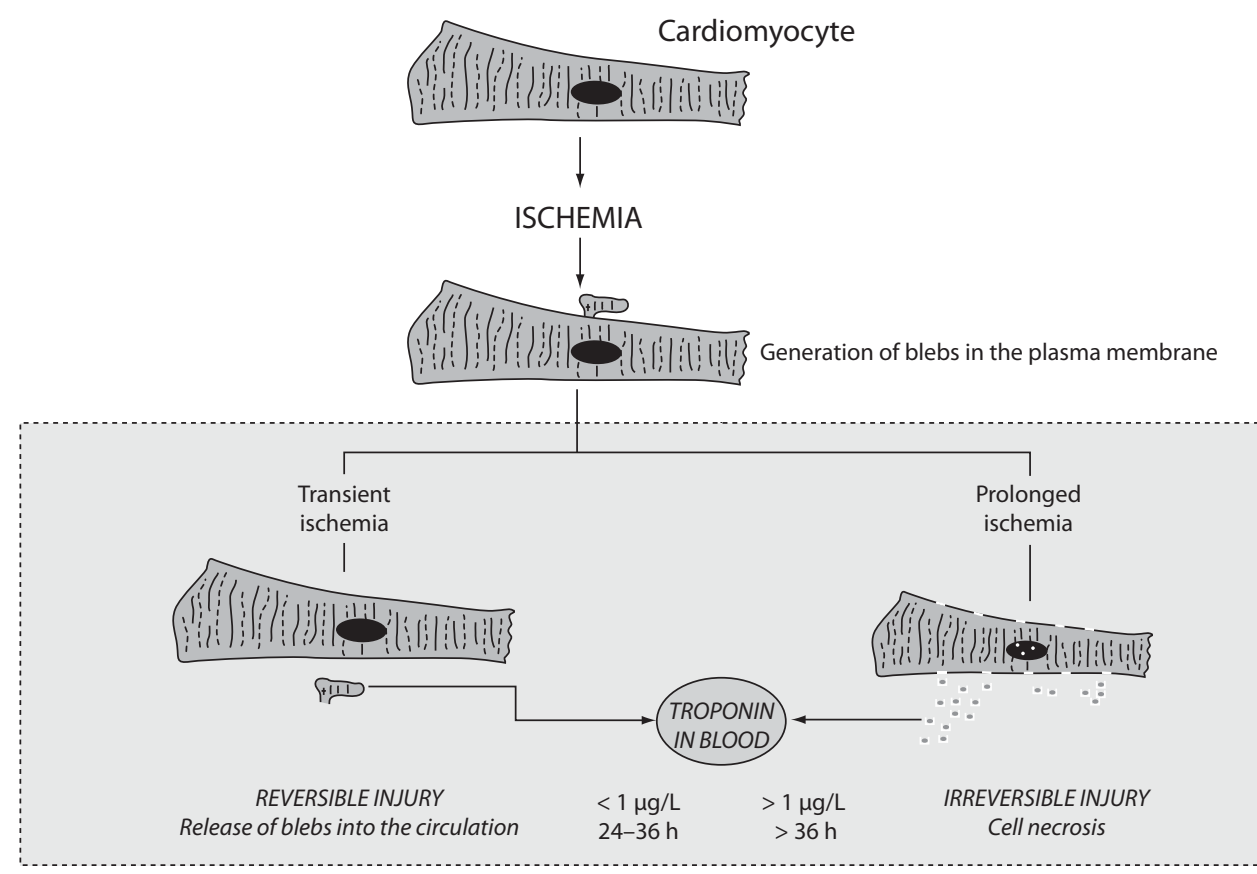

Figure 1. Biological basis underlying the ischemic release of measurable amount of cardiac troponins from cardiomyocites. 
te participants before and after the 2004 and 2005 Boston Marathons with echocardiography and serum biomarkers (8). Sixty percent of participants had increased cTnT > 99th percentile of normal (> $0.01 \mathrm{ng} / \mathrm{mL}$ ), whereas $40 \%$ had a cTnT level at or above the decision limit for acute myocardial necrosis ( $\geq 0.03 \mathrm{ng} / \mathrm{mL}$ ) after the race. Interestingly these troponin increases significantly correlated with post-race diastolic dysfunction, increased pulmonary pressures, and right ventricular dysfunction, and inversely with training mileage. As such, exercise-induced cardiac dysfunction (e.g., right ventricular dysfunction) might be an additional biochemical evidence of cardiac injury after endurance sports, especially in participants with less training.

Recreational sports encompass activities where the primary purpose is participation, but that also hold the inherent goals of improved physical fitness, fun and social involvement. This kind of physi-

\section{References}

1. Jaffe AS. The clinical impact of the universal diagnosis of myocardial infarction. Clin Chem Lab Med 2008;46:1485-8.

2. Lippi G, Targher G, Franchini M, Plebani M. Genetic and biochemical heterogeneity of cardiac troponins: clinical and laboratory implications. Clin Chem Lab Med 2009;47:1183-94.

3. Plebani M, Zaninotto M. Cardiac troponins: what we knew, what we know - where are we now? Clin Chem Lab Med 2009;47:1165-6.

4. Panteghini M. A critical appraisal of experimental factors influencing the definition of the 99th percentile limit for cardiac troponins. Clin Chem Lab Med 2009;47:1179-82.

5. Dodig S. Interferences in quantitative immunochemical methods. Biochem Med 2009;19:50-62.

6. Lippi G, Plebani M. High-sensitive Troponin Testing and the "runner's Syndrome". J Emerg Med. 2009 Aug 12. [Epub ahead of print].

7. Melanson SE, Green SM, Wood MJ, Neilan TG, Lewandrowski EL. Elevation of myeloperoxidase in conjunction with cardiac-specific markers after marathon running. Am J Clin Pathol 2006;126:888-93.

8. Neilan TG, Januzzi JL, Lee-Lewandrowski E, Ton-Nu TT, Yoerger DM, Jassal DS, et al. Myocardial injury and ventricular dysfunction related to training levels among nonelite participants in the Boston marathon. Circulation 2006; 114:2325-33.

9. Roth HJ, Leithäuser RM, Doppelmayr H, Doppelmayr $M$, Finkernagel $H$, von Duvillard SP, et al. Cardiospecificity of the 3rd generation cardiac troponin T assay during and after a $216 \mathrm{~km}$ ultra-endurance marathon run in Death Valley. Clin Res Cardiol 2007;96:359-64. cal activity, which includes mostly amateur running and cycling, is typically less stressful, both physically and mentally, for the participants and it is also endorsed by health agencies and organizations such as the American Heart Association (AHA) and the American College of Sports Medicine (ACSM) for the substantial healthcare benefits, both physical and economical (i.e., reductions in the strain on public healthcare costs due to prevention of several pathologies such as cardiovascular disease, cancer and osteoporosis) (39). Nevertheless, the clear demonstration that even moderate amounts of physical exercise can increase the concentration of cardiac biomarkers, especially when measured with the novel HS assays, requires major clinical focus on this issue (i.e., serial measurement of cardiac biomarkers, detailed clinical history-taking, integration with ECG and imaging findings) to prevent misdiagnosis of ACS and/or MI otherwise healthy persons.

10. Fortescue EB, Shin AY, Greenes DS, Mannix RC, Agarwal S, Feldman $B J$, et al. Cardiac troponin increases among runners in the Boston Marathon. Ann Emerg Med 2007;49:137-43.

11. La Gerche A, Connelly KA, Mooney DJ, Maclsaac Al, Prior $D L$. Biochemical and functional abnormalities of left and right ventricular function after ultra-endurance exercise. Heart 2008;94:860-6.

12. Koller A, Sumann $G$, Griesmacher A, Falkensammer $G$, Klingler A, Fliri $G$, et al. Cardiac troponins after a downhill marathon. Int J Cardiol 2008; 129:449-52.

13. Nie J, Tong TK, Shi Q, Lin H, Zhao J, Tian Y. Serum cardiac troponin response in adolescents playing basketball. Int $J$ Sports Med 2008;29:449-52.

14. Siegel AJ, Januzzi J, Sluss P, Lee-Lewandrowski E, Wood M, Shirey T, Lewandrowski KB. Cardiac biomarkers, electrolytes, and other analytes in collapsed marathon runners: implications for the evaluation of runners following competition. Am J Clin Pathol 2008;129:948-51.

15. Lippi G, Schena F, Montagnana M, Salvagno GL, Guidi GC. Influence of acute physical exercise on emerging muscular biomarkers. Clin Chem Lab Med 2008;46:1313-8.

16. Dawson EA, Whyte GP, Black MA, Jones H, Hopkins N, Oxborough $D$, et al. Changes in vascular and cardiac function after prolonged strenuous exercise in humans. J Appl Physiol 2008; 105:1562-8.

17. Lippi G, Schena F, Salvagno GL, Montagnana M, Gelati M, Tarperi $C$, et al. Influence of a half-marathon run on NTproBNP and troponin T. Clin Lab 2008;54:251-4.

18. Middleton $N$, George $K$, Whyte $G$, Gaze $D$, Collinson $P_{1}$ Shave $R$. Cardiac troponin $T$ release is stimulated by endurance exercise in healthy humans. J Am Coll Cardiol 2008;52:1813-4. 
19. Mingels A, Jacobs L, Michielsen E, Swaanenburg J, Wodzig $W$, van Dieijen-Visser M. Reference population and marathon runner sera assessed by highly sensitive cardiac troponin $T$ and commercial cardiac troponin T and I assays. Clin Chem 2009;55:101-8.

20. Scott JM, Esch BT, Shave R, Warburton DE, Gaze D, George K. Cardiovascular consequences of completing a $160-\mathrm{km}$ ultramarathon.Med Sci Sports Exerc 2009;41:26-34.

21. Jassal DS, Moffat D, Krahn J, Ahmadie R, Fang T, Eschun G, Sharma S. Cardiac injury markers in non-elite marathon runners. Int J Sports Med 2009;30:75-9.

22. Fu F, Nie J, Tong TK. Serum cardiac troponin T in adolescent runners: effects of exercise intensity and duration. Int J Sports Med 2009;30:168-72.

23. Hubble KM, Fatovich DM, Grasko JM, Vasikaran SD. Cardiac troponin increases among marathon runners in the Perth Marathon: the Troponin in Marathons (TRIM) study. Med J Aust 2009;190:91-3.

24. Giannitsis E, Roth HJ, Leithäuser RM, Scherhag J, Beneke $R$, Katus HA. New highly sensitivity assay used to measure cardiac troponin $T$ concentration changes during a continuous 216-km marathon. Clin Chem 2009;55:590-2.

25. Mousavi N, Czarnecki A, Kumar K, Fallah-Rad N, Lytwyn M, Han SY, et al. Relation of biomarkers and cardiac magnetic resonance imaging after marathon running. Am J Cardiol 2009;103:1467-72.

26. Knebel F, Schimke I, Schroeckh S, Peters H, Eddicks S, Schattke $S$, et al. Myocardial function in older male amateur marathon runners: assessment by tissue Doppler echocardiography, speckle tracking, and cardiac biomarkers. J Am Soc Echocardiogr 2009;22:803-9.

27. Serrano-Ostáriz E, Legaz-Arrese A, Terreros-Blanco JL, López-Ramón M, Cremades-Arroyos D, Carranza-García LE, et al. Cardiac biomarkers and exercise duration and intensity $d u-$ ring a cycle-touring event. Clin J Sport Med 2009;19:293-9.

28. Sahlén A, Gustafsson TP, Svensson JE, Marklund T, Winter $R$, Linde C, Braunschweig F. Predisposing factors and consequences of elevated biomarker levels in long-distance runners aged >or $=55$ years. Am J Cardiol 2009;104:1434-40.
29. Serrano-Ostáriz E, Terreros-Blanco JL, Legaz-Arrese A, George $K$, Shave $R$, Bocos-Terraz $P$, et al. The impact of exercise duration and intensity on the release of cardiac biomarkers. Scand J Med Sci Sports. 2009 Nov 17. [Epub ahead of print]

30. Saravia SG, Knebel F, Schroeckh S, Ziebig R, Lun A, Weima $n n A$, et al. Cardiac troponin $T$ release and inflammation demonstrated in marathon runners. Clin Lab 2010;56:51-8.

31. Regwan S, Hulten EA, Martinho S, Slim J, Villines TC, Mitchell J, Slim AM. Marathon Running as a Cause of Troponin Elevation: A Systematic Review and Meta-Analysis. J Interv Cardiol. 2010 Jul 20. [Epub ahead of print].

32. Lippi G, Cervellin G, Plebani M. Sensitive cardiac troponin $T$ assay. N Engl J Med 2010;362:1242.

33. Giannoni A, Giovannini S, Clerico A. Measurement of circulating concentrations of cardiac troponin I and T in healthy subjects: a tool for monitoring myocardial tissue renewal? Clin Chem Lab Med 2009;47:1167-77.

34. Hickman PE, Potter JM, Aroney C, Koerbin G, Southcott $E, W u A H$, Roberts MS. Cardiac troponin may be released by ischemia alone, without necrosis. Clin Chim Acta 2010;411:318-23.

35. Trivax JE, Franklin BA, Goldstein JA, Chinnaiyan KM, Gallagher $M J$, deJong AT, et al. Acute cardiac effects of marathon running. J Appl Physiol 2010;108:1148-53.

36. Wilson $M, O^{\prime}$ Hanlon $R$, Prasad S, Oxborough D, Godfrey $R$, Alpendurada $F$, et al. Biological markers of cardiac damage are not related to measures of cardiac systolic and diastolic function using cardiovascular magnetic resonance and echocardiography after an acute bout of prolonged endurance exercise. Br J Sports Med. 2010 Jun 11. [Epub ahead of print].

37. Lippi G, Banfi G. Exercise-related increase of cardiac troponin release in sports: An apparent paradox finally elucidated? Clin Chim Acta 2010;411:610-1.

38. O'Hanlon $R$, Wilson $M$, Wage $R$, Smith $G$, Alpendurada FD, Wong J, et al. Troponin release following endurance exercise: is inflammation the cause? a cardiovascular magnetic resonance study. J Cardiovasc Magn Reson 2010;12:38.

39. Lippi G, Guidi GC, Nevill A, Boreham C. The growing trend of scientific interest in sports science research. J Sports Sci 2008;26:1-2.

\section{Srčani troponini i tjelovježba}

\section{Sažetak}

Pravovremeno dijagnosticiranje aktunog koronarnog sindroma, a posebice infarkta miokarda, još uvijek predstavlja jedan od najvećih izazova u medicini. Uvođenje testova za mjerenje srčanih troponina u rutinske laboratorijske pretrage znatno je pobolǰsalo dijagnostički pristup, a najnoviji razvoj metoda s poboljšanom analitičkom osjetljivošću (engl. high-sensitive, [HS]; visokoosjetljivi testovi) nadalje je doprinjelo poboljšanju negativne prediktivne vrijednosti kod određivanja koncentracije troponina. Međutim, to je istovremeno značajno snizilo kliničku specifičnost tih biljega.

Klinička su ispitivanja pokazala kod čak 94\% sportaša koji se bave nekim od od sportova izdržljivosti (engl. endurance sports) mjerljivo povišenje koncentracije HS-troponina. Ta povišena koncentracija troponina u krvi ukazuje prije na povećanu propustljivost membrane te rano otpuštanje troponina, nego na klinički opasnu ozlijedu miokarda. Povećana bi koncentracija troponina određena visokoosjetljivim testovima trebala opširnu kliničku obradu (uzastopna mjerenja srčanih biomarkera, detaljno bilježenje kliničke povijesti bolesti, integracija nalaza elektrokardiograma i rezultata slikovne dijagnostičke obrade), kako bi se spriječile pogrešne dijagnoze aktunog koronarnog sindroma i infarkta miokarda kod inače zdravih osoba.

Ključne riječi: sport; biomarkeri; akutni infarkt miokarda; srčana ozljeda; troponin 